\title{
STUDY OF THE EFFECT OF PARACETAMOL BINDED IN POLYMERIC NANOPARTICLES ON DAFNIA MAGNA
}

\author{
${ }^{1}$ Barbora HAVELKOVA, ${ }^{1,2,3}$ Karel SEHNAL, ${ }^{4}$ Dominik BANAS, ${ }^{5}$ Marta KEPINSKA, ${ }^{2,6}$ Branislav \\ RUTTKAY-NEDECKY, ${ }^{2}$ Martina STANKOVA, ${ }^{7}$ Carlos FERNANDEZ, ${ }^{1}$ Miroslava BEKLOVA, and \\ ${ }^{2,3,5}$ Rene KIZEK \\ ${ }^{1}$ Department of Ecology and Diseases of Zooanimals, Game, Fish and Bees, Faculty of Veterinary Hygiene \\ and Ecology, University of veterinary and pharmaceutical sciences, Brno, Czech Republic, EU, \\ havelkovab@vfu.cz, beklovam@vfu.cz \\ ${ }^{2}$ Department of Research and Development, ECO-ENVI-NANOLIFE, Prague, Czech Republic, EU \\ ${ }^{3}$ Department of Pharmacology and Toxicology, Faculty of Pharmacy, Masaryk University, Brno, Czech \\ Republic,EU, karelsehnal15@gmail.com, kizek@sci.muni.cz \\ ${ }^{4}$ Department of Biochemistry, Faculty of Science, Masaryk University, Brno-Bohunice, Czech Republic, EU, \\ dominik.banass@gmail.com \\ ${ }^{5}$ Department of Biomedical and Enviromental Analyses, Faculty of Pharmacy, Wroclaw Medical University, \\ Wroclaw, Poland, EU, marta.kepinska@umed.wroc.pl \\ ${ }^{6}$ Department of Molecular Pharmacy, Faculty of Pharmacy, Masaryk University, Brno, Czech Republic, EU, \\ ruttkay-nedeckyb@pharm.muni.cz
}

${ }^{7}$ School of Pharmacy and Life Sciences, Robert Gordon University, Garthdee Road, Aberdeen, United Kingdom, c.fernandez@rgu.ac.uk

https://doi.org/10.37904/nanocon.2020.3747

\begin{abstract}
Drugs are important xenobiotics in the environment. Their use increases with the growth of the human population, but also in agricultural primary production. Paracetamol (PAR) is a widely used analgesic and antipyretic and its production is still growing. Commonly available drug production technologies are being developed very intensively with nanotechnological modifications for their gradual and targeted release. Nanoparticles (ST/PAR) from starch were prepared: PAR $(0,1,2,3,5$ and $10 \mathrm{mg} / \mathrm{L})$ was mixed with citric acid ester in a $1: 8 \mathrm{v} / \mathrm{v}$ ratio for $30 \mathrm{~min}$ at $25^{\circ} \mathrm{C}$. By the centrifugation $(16.000 \mathrm{~g}, 30 \mathrm{~min})$ ST/PAR were obtained in the pellet. The effect of PAR was studied on Daphnia magna Straus (Cladocera, Crustacea). Adult females (70-400 mg) were used for self-evaluation. The EC50 was $3.749 \mathrm{mg} / \mathrm{L}$ after $48 \mathrm{~h}$ of PAR treatment. Total protein values determined by Lowry method were between $0.5-2.2 \mathrm{mg} / \mathrm{mL}$ and by Bradford method between 190-676 mg/L. Antioxidant activity values determined by CUPRAC method were between $4-15 \mu \mathrm{g} / \mathrm{mL}$ GAE and by ABTS method ranged between $40-103 \mu \mathrm{g} / \mathrm{mL}$ GAE. PAR values were between 9-40 $\mu \mathrm{M}$. Subsequently, the biological activity of the prepared nanoparticles was tested.
\end{abstract}

Keywords: ecotoxicology; chemical and biochemical analysis; nanomedicine

\section{INTRODUCTION}

Drugs are important xenobiotics in the environment. Their use increases with the growth of the human population, but also in primary agricultural production. Paracetamol (PAR) is a non-steroidal anti-inflammatory drug widely used [1]. PAR enters the aquatic environment with wastewater and thus affects aquatic organisms 
$[2,3]$. There is little information on the effect of PAR on detoxification processes. PAR induces oxidative stress, can manifest in endocrine disruption $[3,4]$ and affect the expression of selected genes [1].

The increase in their environmental concentrations in individual components of the environment is obvious, and with the use of modern analytical techniques, residues are detected in soil, surface water, sediments, groundwater, and marine ecosystems [5]. It is highly probable that increasing concentrations of PAR in the aquatic environment and its transformation by the food chain may affect a number of biochemical and physiological processes determining the growth and development of aquatic biocenosis [6]. The importance of PAR monitoring stems from the results of monitoring studies that have shown its high concentrations in wastewater [7,8]. Wastewater treated plants cannot effectively eliminate most medicines, so they are a particularly significant environmental risk for aquatic ecosystems [9]. Little relevant information is available, in particular on the sublethal effects of PAR on aquatic organisms, in addition, the effects of nanoparticle-bound drugs (NPs) are completely unknown. Cladocera Daphnia magna Straus (Cladocera, Crustacea) is not only an important model species in ecotoxicology, but also a planktonic crustacean, which is a key consumer of algae and cyanobacteria, as well as food for many fish [10]. It thus serves as a link between primary phytoplankton production and higher trophic levels in the aquatic ecosystem. Commonly available drug manufacturing technologies are being developed very intensively by nanotechnological modifications for their gradual and targeted release $[11,12]$. Nanotechnological modification of PAR could find application in the treatment of cancer [13]. The aim of this project is to extend existing knowledge about the toxicity of PAR and its nanoform (NPs-PAR) to aquatic organisms. The determined values of acute and chronic toxicity of the monitored substances will allow the estimation of the risk to the aquatic environment.

\section{MATERIAL AND METHODS}

\section{Biological experiments}

The solution and elaboration of the topic presupposes the mastery of selected standard ecotoxicological tests on aquatic crustaceans - Cladocera Daphnia magna. Tests according to ČSN EN ISO 6341 (75 7751) was used to evaluate ecotoxicity. Immobilization test for Daphnia magna Straus (Cladocera, Crustacea) - Acute toxicity test and ČSN ISO 10706 (75 7752 - Determination of chronic toxicity of substances for Daphnia magna Straus (Cladocera, Crustacea). The acute test on Clacodera $D$. magna pearls consists in monitoring their immobilization in a selected range of test substance concentrations at exposure for 24 and 48 hours.

\section{Chemical analysis}

Amount of $150 \mu \mathrm{L}$ LOWRY solution I ( $7 \mathrm{mM}$ Na-K tartrate, $0.81 \mathrm{M}$ sodium carbonate, $0.5 \mathrm{M} \mathrm{NaOH}$ ) was pipetted into cuvettes and then in 9th period (81 s) $9 \mu \mathrm{L}$ of barley extract was added. Afterwards, LOWRY solution II (70 mM Na-K tartrate, $40 \mathrm{mM} \mathrm{CuSO}_{4}$ and $0.1 \mathrm{M} \mathrm{NaOH}$ ) was added in 42nd period (378 s) in volume of $20 \mu \mathrm{L}$ and finally $172 \mu \mathrm{L}$ of LOWRY solution III (1:15 Folin-Ciocalteu reagent: $\mathrm{H}_{2} \mathrm{O}$ ) in 90th period (810 s) was added. Reaction was evaluated as a response in miliabsorbance units between period 93 to 96 (837 seconds to 864 seconds from pipetting of LOWRY I solution). Wavelength: $660 \mathrm{~nm}$. Quality of reagents were controlled via regulation diagram for $188 \mathrm{mg} / \mathrm{L}$ bovine serum albumin standard with good reproducibility of reaction ( $8400 \pm$ $258 \mathrm{mAU}$, RSD $3.07 \%$, 8 days).

PARACETAMOL methodology. Measurement in stems - Approximately $1 \mathrm{~g}$ of sample for each concentrations was crushed with sea sand and $2 \mathrm{~mL}$ of PBS, $\mathrm{pH}=7$ was added. Crushed stems and buffer were quantitatively transferred to $2 \mathrm{~mL}$ eppendorf microtubes and centrifuged for 30 minutes for $16.900 \mathrm{~g}$. Supernatant was pipetted into clear microtubes and concentration of paracetamol was measured. Amount of $320 \mu \mathrm{L}$ of Paracetamol solution I (17.9 mM sodium nitroprusside and $13.4 \mathrm{mM} \mathrm{K}_{3} \mathrm{Fe}(\mathrm{CN})_{6}$ ) was pipetted into cuvettes and then) $40 \mu \mathrm{L}$ of barley extract was added. Afterwards, $40 \mu \mathrm{L}$ of Paracetamol solution II (2 M NaOH) was 
added in 43nd period (559 seconds). Reaction was evaluated as a response in absorbance units in period 146 (1898 s from pipetting of Paracetamol solution 1). Wavelength: $700 \mathrm{~nm} .270 \mu \mathrm{L}$ CUPRAC solution 1 (10 mM $\mathrm{CuSO}_{4} ; 7.5 \mathrm{mM}$ neocuproine in $99 \%$ ethanol and $1 \mathrm{M}$ ammonium acetate in 1:1:1 ratio) was pipetted into cuvettes and then 9th period (81 s) $30 \mu \mathrm{L}$ of sample was added. Reaction was evaluated as a response in miliabsorbance units between period 75 to 79 ( $675 \mathrm{~s}$ to $711 \mathrm{~s}$ from pipetting of PBM solution 1). Wavelength: $450 \mathrm{~nm}$. Quality of reagents were controlled via regulation diagram for two concentrations of gallic acid; 25 $\mu \mathrm{g} / \mathrm{mL}$ and $12.5 \mu \mathrm{g} / \mathrm{mL}$. Based on 7 separate days of measurements, responses for concentration $25 \mu \mathrm{g} / \mathrm{mL}$ are in range of $58804 \pm 1964 \mathrm{mAU}, \mathrm{RSD} 3.34 \%$ and for concentrations $12.5 \mu \mathrm{g} / \mathrm{mL}$ are in range of $34461 \pm$ $2360 \mathrm{mAU}, \mathrm{RSD} 6.85 \%$, which shows good reproducibility of reaction. $200 \mu \mathrm{l}$ ABTS solution 1 (0.7 mM ABTS and $495 \mu \mathrm{M}$ potassium persulfate) was pipetted into cuvettes and then in 9th period (81 s) $45 \mu \mathrm{L}$ of sample was added. Reaction was evaluated as a response in miliabsorbance units between period 75 to 79 (675 seconds to $711 \mathrm{~s}$ from pipetting of PBM solution 1). Wavelength: $660 \mathrm{~nm}$. Quality of reagents were controlled via regulation diagram for two concentrations of gallic acid; $11.5 \mu \mathrm{g} / \mathrm{mL}$ and $5.75 \mu \mathrm{g} / \mathrm{mL}$. Based on 4 separate days of measurements, responses for concentration $11.5 \mu \mathrm{g} / \mathrm{mL}$ are in range of $11149 \pm 2790 \mathrm{mAU}, \mathrm{RSD}$ $25.03 \%$ and for concentrations $5.75 \mu \mathrm{g} / \mathrm{mL}$ are in range of $29636 \pm 4209 \mathrm{mAU}, \mathrm{RSD} 14.20 \%$. Precision is lowered, because ABTS is based on decolourization of the reaction mixture, which is always connected with lower precision. $190 \mu \mathrm{l}$ of Bradford solution I $\left(0.1 \mathrm{~g} / \mathrm{L}\right.$ Coomassie Brilliant Blue; $8.5 \% \mathrm{H}_{3} \mathrm{PO}_{4} ; 3.4 \%$ ethanol) was pipetted into cuvettes and then $10 \mu \mathrm{L}$ of sample was added. Reaction was evaluated as a response in absorbance units in period 45 (598 s from pipetting of Bradford solution 1). Wavelength: $700 \mathrm{~nm}$. $150 \mu \mathrm{L}$ GST solution 1 ( $2 \mathrm{mM} \mathrm{CDNB}$ in $20 \%$ methanol) was pipetted into cuvettes and then in 9th period $(81 \mathrm{~s}) 45 \mu \mathrm{L}$ of sample was added. Afterwards, GST solution II (12.5 mM GSH) was added in 42nd period ( $378 \mathrm{~s}$ ) in volume of $20 \mu \mathrm{L}$. Reaction was evaluated as a response in miliabsorbance units in 80th (end of the reaction) and 42nd period (when GST solution II was added) and activity of GST was calculated via formula. PAR $(0,1,2,3,5,10$ $\mathrm{mg} / \mathrm{L}$ ) were used for acute toxicity testing. At the end of the test, D.magna was washed in distilled water and frozen at $-20^{\circ} \mathrm{C}$. Homogenized in $1 \mathrm{ml}$ of water. PAR concentrations were determined photometrically at 700 $\mathrm{nm}$. Total SH groups (Ellman's method at $405 \mathrm{~nm}$ ), GSH, GSSG (at $450 \mathrm{~nm}$ ), GST (at $480 \mathrm{~nm}$ ) and metallothionein electrochemically by the Brdička method. Total protein levels were determined by pyrogallol, biuret and Bradford methods. In our experimental model, the acute toxicity of PAR was performed in three independent experiments $(n=3)$.

\section{RESULTS AND DISUSSION}

A photometric method based on a colour reaction was designed and tested for rapid analysis of PAR content in samples [14-17]. The method showed very good reproducibility and stability of the reaction, RSD ranged up to $5 \%$ (Figure 1). Subsequently, the method was applied to the determination of PAR in water and in cell homogenates of D.magna.

To date, very little attention has been paid to the evaluation of PAR toxicity to $D$. magna. Some selected summary information can be found in the work of Grung et al. [18]. Kim et al. found that after 21 days of NOEC exposure $(5.72 \mathrm{mg} / \mathrm{mL})$ no effects on reproduction were observed [10]. In a study by Daniel et al., no effect on reproduction was demonstrated in $D$. magna [19]. Even in the detailed assessment of wastewater no significant effects on biological assessment were found [20]. In a study, Ding et al observed chronic effects on reproduction at a concentration of $50 \mathrm{mg} / \mathrm{mL}$ [1]. In the case of acute exposure, an effect on the up-regulation of the HRP96, CYP360A8, CYP314, MRP4 and P-gp genes was observed. However, after $96 \mathrm{~h}$, the expression was already reduced [1]. A detailed study of the effect of PAR was performed by Castro et al. In addition, he recommends assessing the reproduction of the offspring of the F-1 generation. There was an effect on maternal reproduction after PAR (F-1) exposure, although these effects were not very pronounced [21]. In our acute toxicity tests, we observed an EC50 of about $3.749 \mathrm{mg} \mathrm{PAR/L} \mathrm{(Figure} \mathrm{2).}$ 


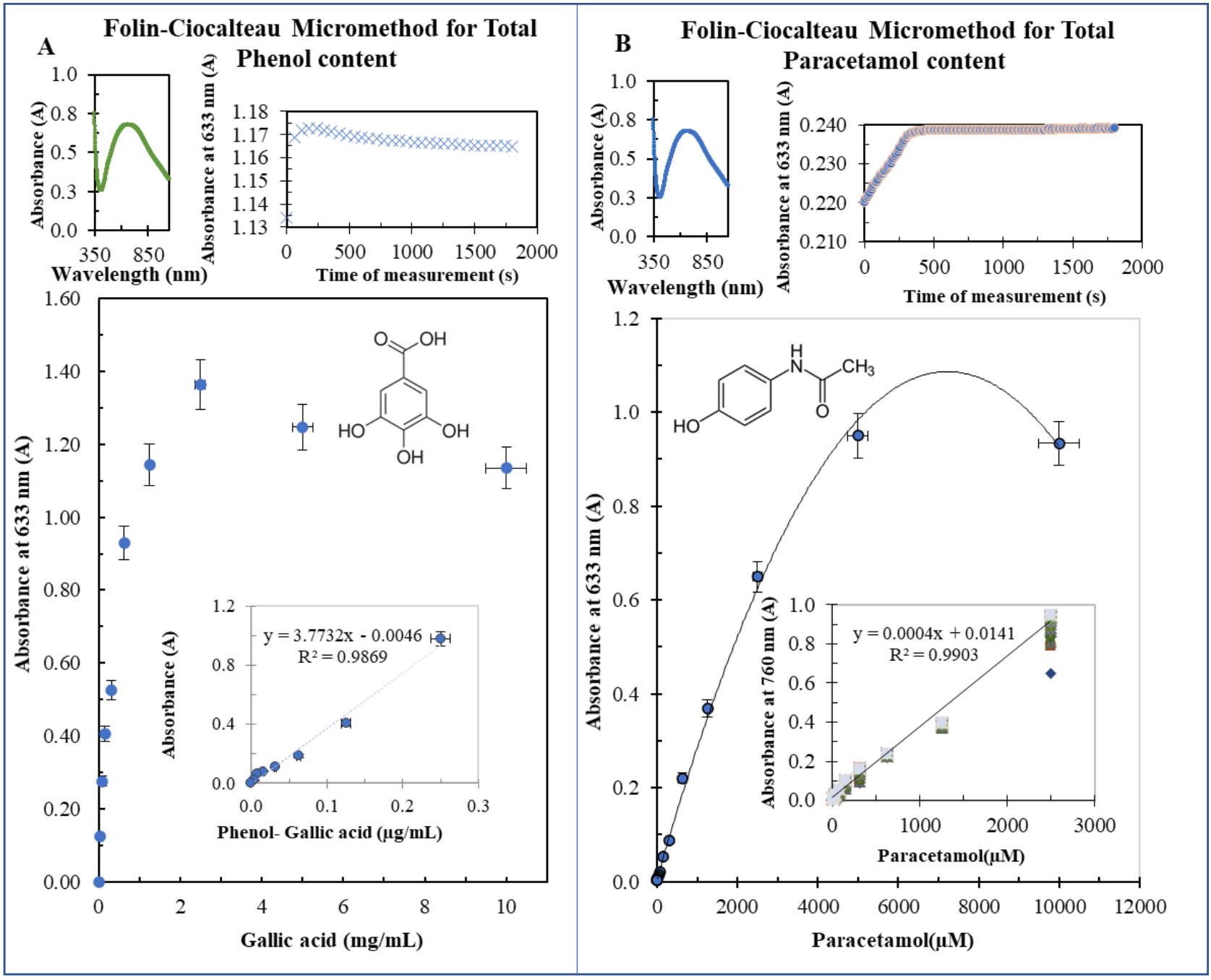

Figure 1 Typical dependence of absorbance on the concentration of gallic acid (GA) - A, and paracetamol (PAR) - B, determined by the Folin-Ciocalteau Micromethod. Typical VIS spectra of GA ( $5 \mathrm{mg} / \mathrm{mL})$ and PAR (5 mM PAR). Stability of the reaction in time 0-2.000 s. Dependence of absorbance on the concentration 0$10 \mathrm{mg} / \mathrm{mL}$ GA and in the insert $0-0.3 \mu \mathrm{g} / \mathrm{ml}$. Dependence of absorbance on the concentration of $0-2.000$ $\mu \mathrm{M}$ PAR in the insert 0-3.000 $\mu \mathrm{M}$.
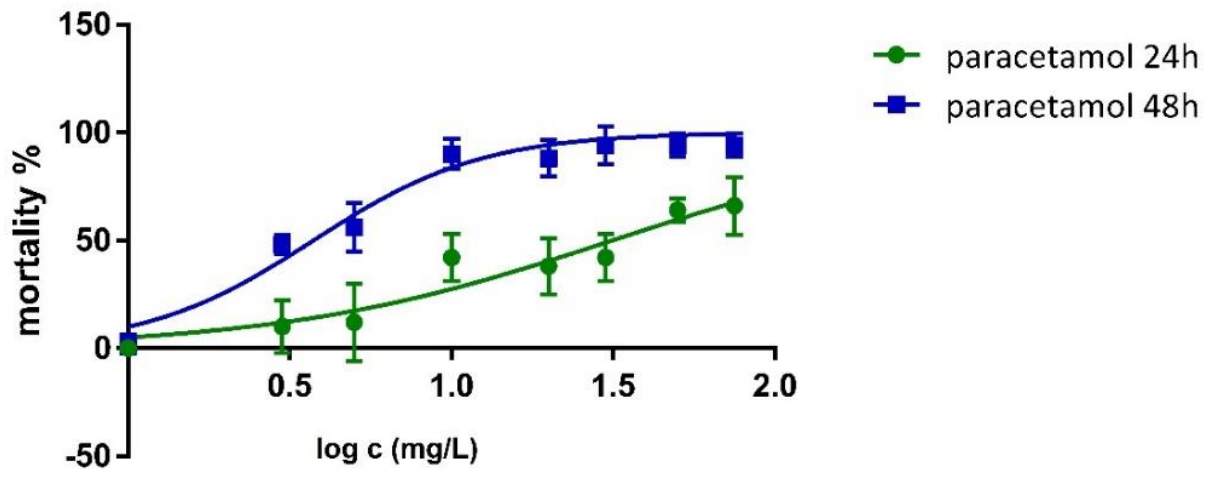

Figure 2 The EC50 for PAR in D. magna were determined at 24 and 48 h 21.48 (24.34 to 40.70) and 3.749 (3.283 to 4.282 ) $\mathrm{mg} / \mathrm{L}$, respectively 
Table1 Chemical analysis of culture water after application of PAR. Each measurement was performed 5 times.

\begin{tabular}{|c|c|c|c|c|c|c|c|c|c|c|c|}
\hline $\begin{array}{c}\text { Sample } \\
\text { name }\end{array}$ & Protein & sodium & potassium & chloride & $\mathrm{pH}$ & conductivity & density & $\begin{array}{c}\text { redox } \\
\text { potential }\end{array}$ & ammonia & $\begin{array}{c}\text { electrochemical } \\
\text { index } \\
\end{array}$ & nitrates \\
\hline $\begin{array}{l}\text { PAR } \\
(1 \mathrm{mg})\end{array}$ & 8.3 & 4.1 & 33.9 & 7.3 & 7.8 & 726.8 & 1.00028 & 19.7 & 415.4 & 16.2 & 1.4 \\
\hline $\begin{array}{l}\text { PAR } \\
(2 \mathrm{mg})\end{array}$ & 13.0 & 10.1 & 24.5 & 4.9 & 7.8 & 699.0 & 1.0003 & 21.9 & 314.6 & 14.2 & 1.3 \\
\hline $\begin{array}{c}\text { PAR } \\
(5 \mathrm{mg})\end{array}$ & 14.5 & 21.6 & 34.7 & 6.0 & 7.8 & 755.6 & 1.0003 & 22.1 & 480.7 & 14.5 & 4.9 \\
\hline
\end{tabular}

Preparation of SPION starch nanoparticles

Starch (100 mg) was dissolved in $20 \mathrm{ml}$ of distilled and deionized water at $80{ }^{\circ} \mathrm{C}$ under magnetic stirring. A 5 $\mathrm{mL}$ portion of solution containing $0.1 \mathrm{M} \mathrm{Fe}^{2+}$ and $0.2 \mathrm{M} \mathrm{Fe}^{3+}$ was poured into a prepared starch solution under vigorous stirring. The starch and iron ion mixture $(25 \mathrm{~mL})$ was then added dropwise into $250 \mathrm{~mL}$ of $0.1 \mathrm{M} \mathrm{NaOH}$ under vigorous mechanical stirring $(2000 \mathrm{rpm} / \mathrm{min})$ at $60{ }^{\circ} \mathrm{C}$ for $2 \mathrm{~h}$. Around $50 \mathrm{wt} \%$ of water was evaporated, and the remaining solution was cooled to room temperature and allowed to stand $12 \mathrm{~h}$. The gels formed were washed with deionized water until the $\mathrm{pH}$ became less than 8.5. Excess salt and ions were removed by using dialysis at $37^{\circ} \mathrm{C}$ for $2-3$ days against $5 \mathrm{~L}$ of distilled water. To cleave glycosidic bond and reduce the polymeric chain to an average molecular weight, the influence of oxidizing agent, used for cleavage of the polymeric starch chains, was investigated. $\mathrm{H}_{2} \mathrm{O}_{2}(5 \mathrm{~mL}$ of $0.46 \mathrm{M})$ was mixed with $20 \mathrm{~mL}(10 \mathrm{mg} / \mathrm{mL})$ of starch-coated SPION. Starch citrate $(0.8 \mathrm{mg} / \mathrm{mL})$ was mixed with paracetamol. The concentration of paracetamol in the reaction mixture was $3205 \mathrm{mM}$. The reaction volume was $1.6 \mathrm{~mL}$. The $2 \mathrm{~mL}$ tube was left on the rotator for 2 hours. Subsequently, it was centrifuged ( $5 \mathrm{~min}, 14.000 \mathrm{~g}$ ) and the paracetamol concentration was measured. Subsequently, $1.6 \mathrm{~mL}$ of water were added, and the mixture was allowed to stir (40 rpm), after which the concentration of the supernatant was measured again. Samples were taken according to $0,30,60,90,120$ and $150 \mathrm{~min}$. The binding of $99 \%$ paracetamol to starch citrate was demonstrated, paracetamol was not released from the binding during the experiment $[11,12]$.

\section{CONCLUSION}

The acute toxicity of PAR to $D$. magna was monitored and subsequently starch nanoparticles were prepared. These nanoparticles were modified with PAR. We found the binding of PAR to the surface of the prepared nanoparticles and PAR was gradually released from the nanoparticles.

\section{ACKNOWLEDGEMENTS}

\section{Supported by the grant FVHE/Pikula/ITA2020}

\section{REFERENCES}

[1] DING, R., LIU, S. J., HE, C. P., NIE, X. P. Paracetamol affects the expression of detoxification- and reproductionrelated genes and alters the life traits of Daphnia magna. Ecotoxicology. 2020, vol. 29, no. 4, pp. 398-406.

[2] MACKULAK, T., SKULCOVA, A., BELISOVA, N., HORAKOVA, I., ZABKA, D., SEMERAD, M., STANOVA, A. V., BRANDEBUROVA, P. Medicines and Drugs: an Environmental Problem? Chemicke Listy. 2019, vol. 113, no. 11, pp. 654-661.

[3] MA, R. X., WANG, B., YIN, L. N., ZHANG, Y. Z., DENG, S. B., HUANG, J., WANG, Y. J., YU, G. Characterization of pharmaceutically active compounds in Beijing, China: Occurrence pattern, spatiotemporal distribution and its environmental implication. Journal of Hazardous Materials. 2017, vol. 323, pp. 147-155. 
[4] PAROLINI, M. Toxicity of the Non-Steroidal Anti-Inflammatory Drugs (NSAIDs) acetylsalicylic acid, paracetamol, diclofenac, ibuprofen and naproxen towards freshwater invertebrates: A review. Science of the Total Environment. 2020, vol. 740, p. 13.

[5] HENSCHEL, K. P., WENZEL, A., DIEDRICH, M., FLIEDNER, A. Environmental Hazard Assessment of Pharmaceuticals. Regulatory Toxicology and Pharmacology. 1997, vol. 25, no. 3, pp. 220-225.

[6] NUNES, B., ANTUNES, S. C., SANTOS, J., MARTINS, L., CASTRO, B. B. Toxic potential of paracetamol to freshwater organisms: A headache to environmental regulators? Ecotoxicology and Environmental Safety. 2014, vol. 107, pp. 178-185.

[7] PIEDADE, F., BIO, S., NUNES, B. Effects of common pharmaceutical drugs (paracetamol and acetylsalicylic acid) short term exposure on biomarkers of the mussel Mytilus spp. Environmental Toxicology and Pharmacology. 2020, vol. 73, p. 10.

[8] GIMENEZ, V., NUNES, B. Effects of commonly used therapeutic drugs, paracetamol, and acetylsalicylic acid, on key physiological traits of the sea snail Gibbula umbilicalis. Environmental Science and Pollution Research. 2019, vol. 26, no. 21, pp. 21858-21870.

[9] AKAY, C., TEZEL, U. Biotransformation of Acetaminophen by intact cells and crude enzymes of bacteria: $\mathrm{A}$ comparative study and modelling. Science of the Total Environment. 2020, vol. 703, p. 11.

[10] KIM, P., PARK, Y., JI, K., SEO, J., LEE, S., CHOI, K., KHO, Y., PARK, J., CHOI, K. Effect of chronic exposure to acetaminophen and lincomycin on Japanese medaka (Oryzias latipes) and freshwater cladocerans Daphnia magna and Moina macrocopa, and potential mechanisms of endocrine disruption. Chemosphere 2012, vol. 89, no. 1, pp. 10-18.

[11] MIOTKE, M., STRANKOWSKA, J., KWELA, J., STRANKOWSKI, M., JOZEFOWICZ, M. Transport of paracetamol in swellable and relaxing polyurethane nanocomposite hydrogels. Polymer Bulletin. 2020, vol. 77, no. 1, pp. 483499.

[12] CHIN, S. F., ROMAINOR, A. N. B., PANG, S. C., LEE, B. K., HWANG, S. S. pH-Responsive Starch-Citrate Nanoparticles for Controlled Release of Paracetamol. Starch-Starke. 2019, vol. 71, no. 9-10, p. 9.

[13] WU, Y. J. J., NEUWELT, A. J., MULDOON, L. L., NEUWELT, E. A. Acetaminophen Enhances Cisplatin- and Paclitaxel-mediated Cytotoxicity to SKOV3 Human Ovarian Carcinoma. Anticancer Research. 2013, vol. 33, no. 6, pp. 2391-2400.

[14] AL-SHWAIYAT, M. K. E. Spectrophotometric Determination of Paracetamol by Reduction of 18-Molybdo-2Phosphate Heteropoly Anion. Jordan Journal of Chemistry. 2013, vol. 146, no. 896, pp. 1-11.

[15] NAGENDRA, P. Spectrophotometric estimation of paracetamol in bulk and pharmaceutical formulations. Journal of Chemistry. 2011, vol. 8, no. 1, pp. 149-152.

[16] SHRESTHA, B. R., PRADHANANGA, R. R. Spectrophotometric method for the determination of paracetamol. Journal of Nepal Chemical Society. 2009, vol. 24, pp. 39-44.

[17] NAGARAJA, P., SRINIVASA MURTHY, K. C., RANGAPPA, K. S. Spectrophotometric method for the determination of paracetamol and phenacetin. Journal of Pharmaceutical and Biomedical Analysis. 1998, vol. 17, no. 3, pp. 501-506.

[18] GRUNG, M., KALLQVIST, T., SAKSHAUG, S., SKURTVEIT, S., THOMAS, K. V. Environmental assessment of Norwegian priority pharmaceuticals based on the EMEA guideline. Ecotoxicology and Environmental Safety. 2008, vol. 71, no. 2, pp. 328-340.

[19] DANIEL, D., DIONISIO, R., DE ALKIMIN, G. D., NUNES, B. Acute and chronic effects of paracetamol exposure on Daphnia magna: how oxidative effects may modulate responses at distinct levels of organization in a model species. Environmental Science and Pollution Research. 2019, vol. 26, no. 4, pp. 3320-3329.

[20] HAN, G. H., HUR, H. G., KIM, S. D. Ecotoxicological risk of pharmaceuticals from wastewater treatment plants in Korea: Occurrence and toxicity to Daphnia magna. Environmental Toxicology and Chemistry. 2006, vol. 25, no. 1, pp. 265-271.

[21] CASTRO, B. B., FRECHES, A. R., RODRIGUES, M., NUNES, B., ANTUNES, S. C. Transgenerational Effects of Toxicants: An Extension of the Daphnia 21-day Chronic Assay? Archives of Environmental Contamination and Toxicology. 2018, vol. 74, no. 4, pp. 616-626. 